Review

\title{
Older residents' perspectives on aged sexuality in institutionalized elderly care: A systematic literature review
}

\author{
Lieslot Mahieu*, Chris Gastmans ${ }^{1}$ \\ Centre for Biomedical Ethics and Law, KU Leuven, Belgium
}

\section{A R T I C L E I N F O}

\section{Article history:}

Received 19 December 2014

Received in revised form 13 July 2015

Accepted 14 July 2015

\section{Keywords:}

Aged

Attitude

Dementia

Residential facilities

Review

Sexual behavior

Sexuality

\begin{abstract}
A B S T R A C T
Objectives: The aim of this systematic literature review is to investigate older residents' thoughts on, experiences of and engagement in sexual behavior and aged sexuality within institutionalized elderly care.

Design: Systematic literature review.

Data sources: We conducted an extensive search of the electronic databases Cinahl, Medline, Pubmed, Embase, Web of Science and Invert for papers published between January 1980 and October 2014 when the searches were closed. Additional papers were identified through forward and backward citation chasing.

Review methods: Data from relevant studies were extracted by means of a data extraction form. Relevant data were isolated, summarized, compared, related and categorized according to theme. Quality assessment of the included studies focused on their adequacy of reporting the study's research aim, sampling, collection, and analysis procedures, ethical considerations and results.

Results: Twenty-five appropriate studies were identified. These studies varied in research design (using surveys, vignettes, focus groups, interviews, or observation), objectives, quality of reporting, and sample characteristics (i.e. male and/or female long-term care residents with and/or without dementia). Yet, they all point to the relevance of sex and sexuality in old age and emphasize the highly individual character of both sexual interest and expression. Older residents who wish to sexually express themselves, might do this in a wide variety of ways, including, but not limited to, daydreaming, dressing-up, looking for emotional and intellectual intimacy, stroking, caressing, kissing, and engaging in sexual intercourse. Overall, residents appear to have a rather positive attitude toward aged sexuality as such. When it comes to specific sexual behaviors or homosexuality, however, attitudes tend to be more negative. The perceived appropriateness of the displayed behavior is a predominant factor in determining older people's reactions to the sexual behavior of co-residents, rather than the potential emotional discomfort brought on by witnessing this behavior.

Conclusions: Relatively little work has been published on older residents' perspectives regarding aged sexuality in institutionalized elderly care. If, however, we wish to devote ourselves to individualized or person-centered nursing care, we will have to gain more insight into the patient's perspective and take notice of the needs,
\end{abstract}

\footnotetext{
* Corresponding author at: Centre for Biomedical Ethics and Law, Kapucijnenvoer 35/3 box 7001, 3000 Leuven, Belgium. Tel.: +32 16373320 ; fax: +32 16336952 .

E-mail addresses: lieslot.mahieu@med.kuleuven.be (L. Mahieu), chris.gastmans@med.kuleuven.be (C. Gastmans).

${ }^{1}$ Address: Centre for Biomedical Ethics and Law, Kapucijnenvoer 35/3 box 7001, 3000 Leuven, Belgium.
} 
expectations, attitudes, experiences and behaviors of residents with regard to (aged) sexuality. Hence more research is needed that depicts the issue of aged sexuality in institutionalized elderly care from a patient's and thus resident oriented perspective.

(c) 2015 Elsevier Ltd. All rights reserved.

\section{What is already known about the topic?}

- Ageist myths and stereotypes portraying old age as asexual are deeply entrenched in our Western society.

- Older people might interiorize ageist stereotypes and feel inclined to act accordingly.

- Although admission to a long-term care facility does not necessarily diminish older people's interest in sex, it often does hamper their sexual expression.

\section{What this paper adds}

- Research on the topic of aged sexuality in institutionalized elderly care often neglects to incorporate the resident's perspective.

- Given the highly individual character of sexual interest and expression in later life, an individualized, holistic care approach warrants greater attention to be given to older residents' thoughts on, experiences of and engagement in sexual behavior and aged sexuality.

\section{Introduction}

Even though aged sexuality is often considered to be 'a contradiction in terms' and thus non-existent, there is a growing body of research that demonstrates the relevance of sex and sexuality to older people (Bauer et al., 2007; Delamater, 2012; Gott, 2005). Sexuality indeed appears to be an essential part of human existence regardless of one's age (Di Napoli et al., 2013; WHO, 2006). Research has shown that people still have sexual desires and might remain sexually active well into their 70's and 80's (Delamater, 2012). The way in which they sexually express themselves might, nevertheless, be interfered with by a myriad of factors such as age-related health issues, the lack or loss of a partner, and perhaps admission to a long-term care facility. Because of various reasons, staying in a longterm care facility might be a barrier to sexual expression. Research has shown that the overall lack of physical privacy and privacy of information, negative staff attitudes, the absence of a sexual partner, and the focus on safety and physical care needs often prevailing in long-term care facilities might impede residents' sexual expression (Elias and Ryan, 2011; Hajjar and Kamel, 2003; Makimoto et al., 2014). Thus, even though institutionalization does not automatically diminish older people's interest in sex, it often does hamper their engagement in sexual activity.

Despite the growing attention paid to the topic of aged sexuality in general, studies addressing sexuality issues in institutionalized elderly care are still relatively scarce (Elias and Ryan, 2011). Rather than focusing on the resident perspective, most reviews on aged sexuality in long-term care settings either adopt a bird-eyes view on the matter (Bauer et al., 2007; Bouman et al., 2006; Makimoto et al., 2014; Parker, 2006; Roelofs et al., 2014) or zoom in on a specific issue of importance such as barriers to residents' sexual expression (Elias and Ryan, 2011; Hajjar and Kamel, 2003), the attitudes and knowledge of nursing staff (Mahieu et al., 2011), and sexual abuse or hypersexuality (Rosen et al., 2010; Tucker, 2010). However, since both the need for and expression of sexual intimacy are highly individual (Bauer et al., 2007; Gott, 2005); it is of critical importance to gain insight into the residents' views and experiences of sexuality and sexual expression in institutionalized elderly care (Elias and Ryan, 2011; Mahieu et al., 2014; Roelofs et al., 2014). After all, they are the main consumers of care in this context. A better understanding of residents' perspectives and experiences of sexuality and sexual expression is crucial if we want to improve care practices and enhance residents' quality of life.

\section{Aim}

The overall aim of this systematic literature review was to investigate how institutionalized older people think about, experience and engage in sexual behavior and aged sexuality within institutionalized long-term care settings for older people.

\section{Methods}

\subsection{Search strategy}

Relevant papers were identified by means of a systematic electronic database search (Greenhalgh and Peacock, 2005; Liberati et al., 2009) of the following databases: Cinahl, Medline, Pubmed, Embase, Web of Science and Invert. The same two search strings were used in each database. These search strings were ((sexuality OR intimacy) AND (older people OR older age OR residents)) AND (long-term care OR nursing home); and ((sexuality OR intimacy) AND (older people OR older age OR residents)) AND (long-term care OR nursing home) AND (attitudes OR knowledge OR experience). If, however, they did not produce any results, additional searches were conducted to broaden the scope of the search. Search outputs were merged and duplicates were removed prior to inclusion assessment. The reference and citation lists of relevant articles were checked in order to identify additional studies (Greenhalgh and Peacock, 2005). Fig. 1 outlines the entire search process from electronic database searching to final selection for review. This figure follows the overall structure of the PRISMA flow diagram which 
Search strings used separately in each database (except Invert*):

1. ((sexuality OR intimacy) AND (older people OR older age OR residents)) AND (long-term care OR nursing home)

2. ((sexuality OR intimacy) AND (older people OR older age OR residents)) AND (long-term care OR nursing home) AND (attitudes OR knowledge OR experience)

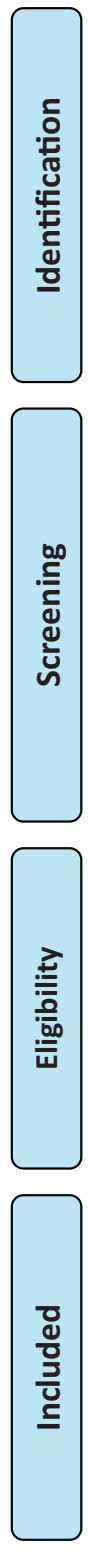

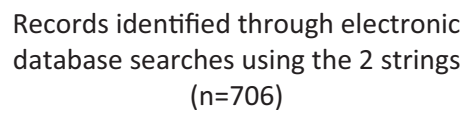

Records identified through electronic database searches using the 2 strings $(n=706)$

Additional records identified through other sources

$$
(n=2)
$$

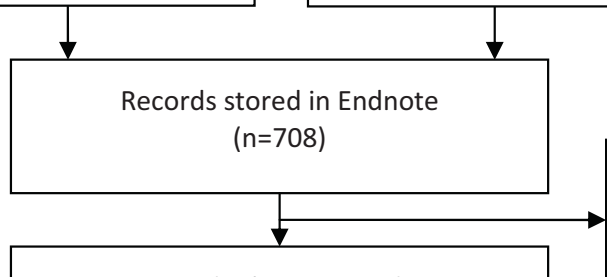

Duplicate records excluded $(n=380)$

Number of duplicated references: $n=76$

Non-duplicate records $(n=328)$

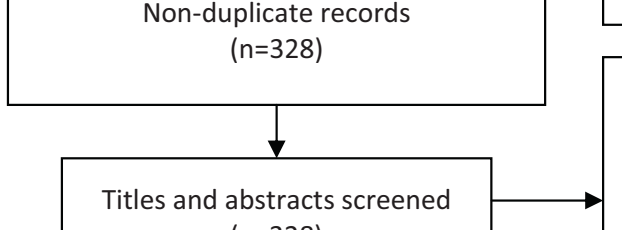

Records excluded, with reasons $(n=300)$

Language: $\mathrm{n}=5$

Year of publication: $n=5$

Publication format: $n=5$

Topic $^{\dagger}: \mathrm{n}=150$

Publication type/study design ${ }^{\ddagger}: \mathrm{n}=92$

Population participation ${ }^{\#}: n=43$

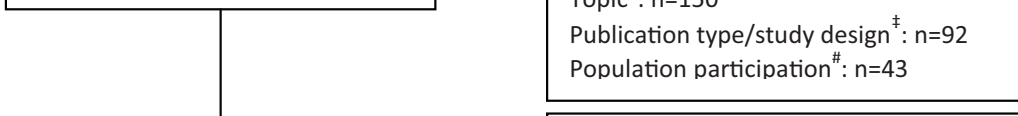

Full-text articles excluded, with reasons

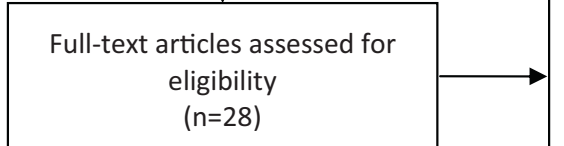

Topic $^{\dagger}: n=0$ ( $n=12)$

Publication type/study design ${ }^{\ddagger}: n=7$ Population participation ${ }^{\#}: n=5$

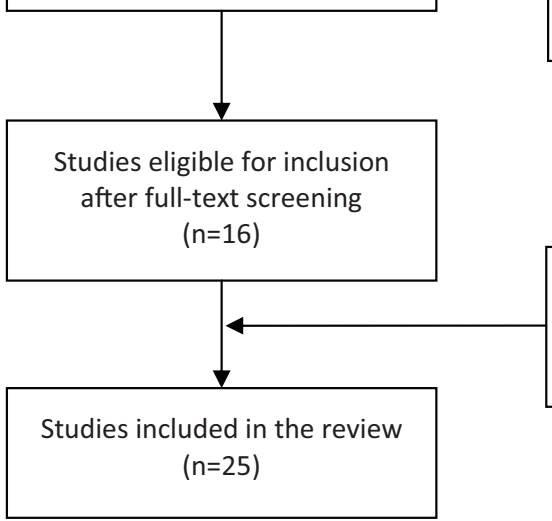

Studies eligible for inclusion identified through snowballing $(n=9)$

* Additional search strings used separately: (1) seksualiteit EN ouderenzorg; (2) seksualiteit EN ouderen; (3) seksualiteit En ouderen En attitudes

† Types of outcome measures: only articles addressing older residents' needs, experiences, preferences, desires, attitudes, behaviors, responses, perceptions, feelings and/or understandings with regard to sexuality in institutionalized long-term care for older people.

‡ Types of studies: only empirical research with a quantitative, qualitative, or mixed method design; no theoretical articles, overview articles, reviews, editorials, etc.

\# Types of participants: only older people living in an institutionalized long-term care setting (i.e. an assisted care facility, a residential or retirementf acilitv. or a nursing home: no hospices or hospitals)

Fig. 1. Electronic search for literature identification and the selection process. 
was specifically designed to transparently summarize study selection processes (Liberati et al., 2009).

\subsection{Inclusion/exclusion criteria}

Title, abstract and full text screening was based on a predetermined set of inclusion and exclusion criteria (Liberati et al., 2009). Articles were only included if they met all the criteria.

\subsubsection{Types of studies}

Included in this review are studies that reported on primary, empirical research using a quantitative, qualitative or mixed method approach. To be eligible studies had to be published (1) as a journal article (2) between January 1980 and October 2014 (3) in English, Dutch, French or German.

Dissertations, books, book chapters, conference papers, theoretical articles, overview articles, reviews, and editorials were excluded; as were articles published outside the abovementioned timespan and/or in another language. Case reports, case studies and retrospective studies solely focusing on care records were also excluded as they lacked the 'lived experience' component we were looking for. The sexual revolution and the rise of the positive aging movement in the 1960s and 1970s have had a tremendous impact on contemporary thinking about aging and sexuality (Gott, 2005). We therefore decided to look for studies published after these turbulent years of change, thus from the 1980s onwards. Language criteria for inclusion were set based on the command of language and linguistic competence of both authors (LM, CG).

\subsubsection{Types of participants}

Studies were only included if they involved residents living in an institutionalized long-term care setting for older people (i.e. an assisted living facility, a residential or retirement facility, or a nursing home). Studies inquiring upon the perspectives and experiences of older hospital patients were excluded. Although these people are staying in an institutionalized care setting, we do believe there is a difference in experience between staying in a hospital and living in a residential long-term care setting for older people. Upon admission, residential aged care facilities become home to their residents. Much more than hospitals these facilities thus find themselves confronted with the necessity of creating a home like environment; that is an environment that allows for residents to continue their daily life activities as much as possible. At least to some, sexuality and sexual activity are an integral part of these activities. Hospices were left out of consideration because of their specific focus on palliation, pain management and symptom control. The specific situation in which hospice patients find themselves is likely to affect the way in which these residents experience and express their sexuality. Studies involving community-dwelling older people were excluded as we specifically looked for institutionalized older residents. Studies including both community-dwelling and institutionalized older people were only considered for inclusion if they provided separate results for both groups. Studies focusing on cognitively intact older residents and/or residents with dementia qualified for inclusion.

\subsubsection{Types of outcome measures}

In order to be eligible for inclusion, studies had to report on outcome measures that were significant for this review and thus explored residents' perspectives on aged sexuality in institutionalized elderly care. This means that a broad spectrum of often interrelated factors and outcome measures had to be considered. We therefore included studies that directly and indirectly dealt with older residents' thoughts about, experiences of and engagement in sexual behavior and aged sexuality. The latter - that is older residents' engagement in sexual behavior - mainly refers to the way in which residents express themselves sexually. Hence, studies were considered for inclusion if they reported on older residents' needs, experiences, preferences, desires, attitudes, behaviors, responses, perceptions, feelings and/or understandings with regard to sexuality in institutionalized long-term care for older people. Medical and pharmacological research focusing solely on sexual (dys)function did not qualify for inclusion. The same is true for studies that deal with the wider context of social interactions and social support without substantially touching upon the topic of intimacy or sexuality and studies that solely seek to describe expressions of inappropriate sexual behavior or hypersexuality by older residents with dementia.

\subsection{Search outcome and quality appraisal}

The electronic searches resulted in the identification of 25 relevant studies of which 11 used a quantitative research design (Table $1 \mathrm{a}$ ). The remaining 14 studies applied qualitative research methods (Table $1 \mathrm{~b}$ ). No mixed method studies combining both quantitative and qualitative research methods were included. The quality of the included studies was appraised based on their adequacy of reporting (Table 2): Are we, as readers, presented with a clear description of the study's research aim, the background literature, the study design, the sampling methods and criteria, the data collection and analysis procedures, the ethical considerations and the study results? This brief appraisal was intended as indicative rather than evaluative and thus played no role in the selection process. Please keep in mind that the relationship between the quality of reporting and the actual methodological soundness of a study might be inconsistent or uncertain.

\subsection{Data extraction and synthesis}

Relevant data were collected by means of a data extraction form covering the following elements: complete reference, author details, year of publication, identification method (i.e. electronic database search, snowballing, 'personal knowledge'), research aim, country and setting, number of participants, age range of the participants, design, data collection and analysis, ethical considerations, quality appraisal, and main results. Data extraction forms were completed by LM in consultation with CG. If there 
Table 1a

Summary characteristics of the quantitative studies included in the literature review.

\begin{tabular}{|c|c|c|c|c|c|c|}
\hline & Study & Country & Design & Participants & Aim & Key findings \\
\hline 1. & $\begin{array}{l}\text { Aizenberg } \\
\text { et al. (2002) }\end{array}$ & Israel & $\begin{array}{l}\text { Survey } \\
\text { study }\end{array}$ & $\begin{array}{l}15 \text { men and } 16 \text { women } \\
\text { residing at the same } \\
\text { nursing home; all } \\
\text { cognitively intact }\end{array}$ & $\begin{array}{l}\text { To evaluate sexual attitudes in } \\
\text { a group of nursing home } \\
\text { residents }\end{array}$ & $\begin{array}{l}\text { Sex appears to be moderately } \\
\text { important to nursing home } \\
\text { residents. A majority of the } \\
\text { participants expressed the } \\
\text { willingness to receive medical } \\
\text { consultation or treatment for sexual } \\
\text { dysfunction as needed and advised } \\
\text { health professionals to openly } \\
\text { discuss sexuality with older } \\
\text { patients. }\end{array}$ \\
\hline 2. & $\begin{array}{l}\text { Bretschneider } \\
\text { and McCoy } \\
(1988)\end{array}$ & USA & $\begin{array}{l}\text { Survey } \\
\text { study }\end{array}$ & $\begin{array}{l}100 \text { men and } 102 \text { women } \\
\text { living in various } \\
\text { retirement homes }(n=10) \\
\text { aged } 80-102 \text { [PR: } 33.7 \%] \\
\text { participants are physically } \\
\text { and mentally healthy }\end{array}$ & $\begin{array}{l}\text { To investigate sexual interest } \\
\text { and behavior in older people } \\
\text { over } 80 \text { living in a residential } \\
\text { retirement facility }\end{array}$ & $\begin{array}{l}\text { Sex was considered to be of at least } \\
\text { average importance by } 66 \% \text { of the } \\
\text { men and } 38 \% \text { of the women at the } \\
\text { moment of questioning. Present and } \\
\text { past importance proved to be } \\
\text { significantly related. A majority of } \\
\text { the participants did not experience } \\
\text { their current living environment as } \\
\text { being particularly unconducive } \\
\text { toward sexual expression. Both } \\
\text { male and female residents still } \\
\text { engaged in touching and caressing } \\
\text { ( } 83 \% \text { and } 64 \% \text {, respectively) and in } \\
\text { sexual intercourse ( } 62 \% \text { and } 30 \% \text {, } \\
\text { respectively). }\end{array}$ \\
\hline 3. & $\begin{array}{l}\text { Bullard-Poe } \\
\text { et al. (1994) }\end{array}$ & USA & $\begin{array}{l}\text { Vignette } \\
\text { study }\end{array}$ & $\begin{array}{l}45 \text { male residents of a } \\
\text { Veterans Affairs nursing } \\
\text { home aged } 44-99 \text {; Mini- } \\
\text { Mental State scores } \geq 15 \text { / } \\
30\end{array}$ & $\begin{array}{l}\text { To describe the relative } \\
\text { importance of social, } \\
\text { intellectual, emotional and } \\
\text { physical intimacy for older } \\
\text { men living in a nursing home, } \\
\text { to delineate the contribution of } \\
\text { these four components of } \\
\text { intimacy to quality of life }\end{array}$ & $\begin{array}{l}\text { Participants' importance ratings } \\
\text { revealed the following hierarchy: } \\
\text { social intimacy (18.7), non-sexual } \\
\text { physical intimacy (17.7), } \\
\text { intellectual intimacy (16.6), } \\
\text { emotional intimacy (15.0) and } \\
\text { sexual physical intimacy (13.7). } \\
\text { Social, non-sexual physical and } \\
\text { intellectual intimacy were } \\
\text { significantly related with life } \\
\text { satisfaction. }\end{array}$ \\
\hline 4. & $\begin{array}{l}\text { De Bruyn } \\
\text { (1980) }\end{array}$ & Netherlands & $\begin{array}{l}\text { Survey } \\
\text { study }\end{array}$ & $\begin{array}{l}30 \text { older people residing at } \\
\text { the same nursing home } \\
\text { aged } 75-90\end{array}$ & $\begin{array}{l}\text { To explore the impact of } \\
\text { institutionalization on nursing } \\
\text { home residents' sexual } \\
\text { experiences }\end{array}$ & $\begin{array}{l}\text { Residents expressed their sexuality } \\
\text { through daydreaming, reminiscing, } \\
\text { reading, complimenting, holding } \\
\text { hands, kissing, caressing, } \\
\text { masturbating and physical } \\
\text { closeness. None of the participants } \\
\text { still engaged in sexual intercourse. } \\
\text { One third criticized the lack of } \\
\text { privacy in the nursing home and } 10 \% \\
\text { felt lonely. }\end{array}$ \\
\hline 5. & $\begin{array}{l}\text { Gibson } \\
\text { et al. (1999) }\end{array}$ & Canada & $\begin{array}{l}\text { Survey } \\
\text { study }\end{array}$ & $\begin{array}{l}72 \text { older people residing at } \\
\text { a chronic care hospital } \\
\text { [PR: } 40 \% \text { ]; ( } 43 \text { community } \\
\text { residing spouses [PR: } 42 \%] \\
\text { and } 388 \text { caregivers) }\end{array}$ & $\begin{array}{l}\text { To compare the opinions of } \\
\text { institutionalized older people, } \\
\text { (caregivers, and community } \\
\text { residing spouses) regarding the } \\
\text { sexual expression of older } \\
\text { people residing in a long-term } \\
\text { care facility }\end{array}$ & $\begin{array}{l}\text { Privacy was the determining factor } \\
\text { when evaluating the } \\
\text { appropriateness of masturbation, } \\
\text { sexual relations and the use of } \\
\text { sexual materials. Responses to } \\
\text { inappropriate sexual behavior and } \\
\text { determinants of such like behavior } \\
\text { varied from population to } \\
\text { population. }\end{array}$ \\
\hline 6. & $\begin{array}{l}\text { Hesse et al. } \\
(1980)\end{array}$ & Germany & $\begin{array}{l}\text { Survey } \\
\text { study }\end{array}$ & $\begin{array}{l}113 \text { older singles residing } \\
\text { at a residential aged care } \\
\text { facility }\end{array}$ & $\begin{array}{l}\text { To explore older residents } \\
\text { experiences related to sexual } \\
\text { and loving relationships in } \\
\text { later life, to investigate which } \\
\text { characteristics are } \\
\text { predominant when choosing a } \\
\text { new partner }\end{array}$ & $\begin{array}{l}\text { Overall single residents seem to } \\
\text { hold rather positive attitudes } \\
\text { toward older couples. When looking } \\
\text { for a new partner a variety of } \\
\text { characteristics are considered. They } \\
\text { mainly want a partner who is } \\
\text { helpful, reliable and offers a sense of } \\
\text { security. Every fifth correspondent } \\
\text { indicated that physical intimacy } \\
\text { would be important }\end{array}$ \\
\hline
\end{tabular}


Table 1a (Continued)

\begin{tabular}{|c|c|c|c|c|c|c|}
\hline & Study & Country & Design & Participants & Aim & Key findings \\
\hline 7. & $\begin{array}{l}\text { Mroczek } \\
\text { et al. (2013) }\end{array}$ & Poland & $\begin{array}{l}\text { survey } \\
\text { study }\end{array}$ & $\begin{array}{l}85 \text { older nursing home } \\
\text { residents aged } 58-92 ; \\
\text { residents with a diagnosis } \\
\text { of dementia were } \\
\text { deliberately excluded }\end{array}$ & $\begin{array}{l}\text { To analyze psychosexual needs } \\
\text { of nursing home residents and } \\
\text { investigate whether and how } \\
\text { these needs are satisfied }\end{array}$ & $\begin{array}{l}\text { Most respondents ranked the need } \\
\text { for conversation as the most } \\
\text { important followed by the need for } \\
\text { respect, the need for tenderness, the } \\
\text { need for support, the need for } \\
\text { physical closeness and the need for } \\
\text { living together. Slightly more than } \\
\text { half of the participants still felt } \\
\text { sexual tension. This tension was } \\
\text { relieved through sexual intercourse, } \\
\text { masturbation, watching erotic films } \\
\text { or diverting attention. Only one } \\
\text { third of the participants succeeded } \\
\text { in satisfying their psychosocial } \\
\text { needs. }\end{array}$ \\
\hline 8. & $\begin{array}{l}\text { Mulligan and } \\
\text { Palguta (1991) }\end{array}$ & USA & $\begin{array}{l}\text { Survey } \\
\text { study }\end{array}$ & $\begin{array}{l}61 \text { male residents of a } \\
\text { Veterans Affairs nursing } \\
\text { home aged } 42-100 ; \\
\text { residents with severe } \\
\text { cognitive impairment } \\
\text { (MMS score }<15 \text { ) were } \\
\text { deliberately excluded }\end{array}$ & $\begin{array}{l}\text { To describe sexual interest, } \\
\text { activity, and satisfaction } \\
\text { among nursing home residents }\end{array}$ & $\begin{array}{l}\text { A strong preference for vaginal } \\
\text { intercourse was detected. The level } \\
\text { of sexual activity, however, was low } \\
\text { for both residents with and without } \\
\text { a current partner. Of the } \\
\text { respondents with a partner } 17 \% \text { still } \\
\text { engaged in sexual intercourse on a } \\
\text { monthly basis; } 70 \% \text { still kissed or } \\
\text { hugged their partner at least once a } \\
\text { month and } 10 \% \text { masturbated. Most } \\
\text { residents were relatively satisfied } \\
\text { sexually. }\end{array}$ \\
\hline 9. & $\begin{array}{l}\text { Spector and } \\
\text { Fremeth (1996) }\end{array}$ & Canada & $\begin{array}{l}\text { Survey } \\
\text { study }\end{array}$ & $\begin{array}{l}40 \text { cognitively intact older } \\
\text { residents of } 2 \text { long-term } \\
\text { care facilities aged 69-95 }\end{array}$ & $\begin{array}{l}\text { To explore the sexual attitudes } \\
\text { and behaviors of residents }\end{array}$ & $\begin{array}{l}\text { The level of sexual activity among } \\
\text { residents was extremely low for the } \\
\text { month prior to filling out the } \\
\text { questionnaire. A large majority of } \\
\text { the participants had not engaged in } \\
\text { solitary or dyadic sexual activity } \\
\text { during the past month ( } 90 \% \text { and } \\
87.5 \% \text {, respectively). Men reported } \\
\text { significantly higher levels of sexual } \\
\text { desire and significantly lower levels } \\
\text { of sexual satisfaction than women. }\end{array}$ \\
\hline 10. & Story (1989) & USA & $\begin{array}{l}\text { Survey } \\
\text { study }\end{array}$ & $\begin{array}{l}133 \text { well older people } \\
\text { living in a retirement } \\
\text { home aged } 65 \text { or older }\end{array}$ & $\begin{array}{l}\text { To determine the knowledge } \\
\text { and attitudes of well older } \\
\text { people living in a retirement } \\
\text { home toward aged sexuality, to } \\
\text { explorer the influence of } \\
\text { demographic variables on } \\
\text { sexual knowledge and attitude } \\
\text { scores }\end{array}$ & $\begin{array}{l}\text { Student respondents outscored the } \\
\text { older residents on knowledge. Both } \\
\text { had a rather positive attitude } \\
\text { toward aged sexuality in general. } \\
\text { However, when it came to specific } \\
\text { sexual behaviors such as oral genital } \\
\text { activity and sex outside marriage } \\
\text { residents proved to be more } \\
\text { conservative and less tolerant than } \\
\text { students. Respondents with a higher } \\
\text { knowledge level appeared to hold } \\
\text { more positive attitudes. }\end{array}$ \\
\hline 11. & White (1982) & USA & $\begin{array}{l}\text { Survey } \\
\text { study }\end{array}$ & $\begin{array}{l}250 \text { residents dispersed } \\
\text { over a stratified random } \\
\text { sample of } 15 \text { nursing } \\
\text { homes }\end{array}$ & $\begin{array}{l}\text { To explore the relationship } \\
\text { between certain individual } \\
\text { variables (i.e. sexual interest, } \\
\text { sexual attitudes, sexual } \\
\text { knowledge, and sexual history) } \\
\text { and sexual activity in } \\
\text { institutionalized elderly care }\end{array}$ & $\begin{array}{l}\text { Slightly more than } 90 \% \text { if the } \\
\text { participants had not engaged in } \\
\text { sexual intercourse of masturbation } \\
\text { in the month prior to the filling out } \\
\text { the questionnaire. Of these sexually } \\
\text { inactive residents, } 17 \% \text { indicated } \\
\text { that they wished to be sexually } \\
\text { active but lacked the opportunity. } \\
\text { Residents' sexual history appeared } \\
\text { to be an important predictor of } \\
\text { current sexual activity. Knowledge } \\
\text { and attitude scores were not } \\
\text { significantly related. }\end{array}$ \\
\hline
\end{tabular}

PR: participation rate. 
Table $1 \mathrm{~b}$

Summary characteristics of the qualitative studies included in the literature review.

\begin{tabular}{|c|c|c|c|c|c|c|}
\hline & Study & Country & Design & Participants & Aim & Key findings \\
\hline 1. & $\begin{array}{l}\text { Bauer } \\
\text { et al. (2013) }\end{array}$ & Australia & $\begin{array}{l}\text { Interview } \\
\text { study }\end{array}$ & $\begin{array}{l}16 \text { older residents } \\
\text { dispersed over } 6 \text { aged care } \\
\text { facilities of which } 5 \text { had a } \\
\text { confirmed diagnosis of } \\
\text { dementia (early stage) }\end{array}$ & $\begin{array}{l}\text { To explore older residents' } \\
\text { experiences of the need for and } \\
\text { barriers to the expression of } \\
\text { sexuality in residential aged } \\
\text { care }\end{array}$ & $\begin{array}{l}\text { Older residents still think about } \\
\text { sex. While some still wish to be } \\
\text { sexually active, others simply } \\
\text { consign the expression of } \\
\text { sexuality to the past. Aged care } \\
\text { facilities seem to be unconducive } \\
\text { to the expression of sexuality. }\end{array}$ \\
\hline 2. & $\begin{array}{l}\text { Donaldson } \\
\text { et al. (2014) }\end{array}$ & USA & $\begin{array}{l}\text { Interview } \\
\text { study }\end{array}$ & $\begin{array}{l}13 \text { heterosexual assisted } \\
\text { living facility residents } \\
\text { aged } 62-90\end{array}$ & $\begin{array}{l}\text { To examine the attitudes of } \\
\text { heterosexual assisted living } \\
\text { facility residents toward gay } \\
\text { and lesbian peers in their } \\
\text { facility, to explore the role of } \\
\text { previously identified factors in } \\
\text { attitudes toward gay and } \\
\text { lesbian people }\end{array}$ & $\begin{array}{l}\text { Heterosexual older residents' } \\
\text { attitudes toward gay and lesbian } \\
\text { peers range from unfavorable, to } \\
\text { ambivalent, to favorable. They } \\
\text { are often ignorant about the } \\
\text { sexual orientation of co- } \\
\text { residents. Great importance was } \\
\text { attached to the need for } \\
\text { appropriate boundaries and } \\
\text { privacy. }\end{array}$ \\
\hline 3. & $\begin{array}{l}\text { Ehrenfeld } \\
\text { et al. (1999) }\end{array}$ & Israel & $\begin{array}{l}\text { Observational } \\
\text { study }\end{array}$ & $\begin{array}{l}48 \text { residents dispersed } \\
\text { over } 8 \text { homes for older } \\
\text { people, (their family } \\
\text { members and staff), } 90 \% \\
\text { of the residents had stage } \\
2 \text { dementia, } 10 \% \text { had stage } \\
1 \text { dementia }\end{array}$ & $\begin{array}{l}\text { To explore the sexual behavior } \\
\text { of institutionalized older } \\
\text { people with dementia and to } \\
\text { investigate the reactions of } \\
\text { other residents, (family } \\
\text { members and staff) to this } \\
\text { behavior }\end{array}$ & $\begin{array}{l}\text { The sexual behavior of nursing } \\
\text { home residents with dementia } \\
\text { can be distinguished into } 3 \\
\text { categories: love and caring, } \\
\text { romance, and eroticism. Most } \\
\text { sexually-based behavior } \\
\text { occurred between men and } \\
\text { women and was initiated by the } \\
\text { former. Reactions to the sexual } \\
\text { behavior of co-residents ranged } \\
\text { from total indifference to plain } \\
\text { anger. }\end{array}$ \\
\hline 4. & $\begin{array}{l}\text { Frankowski } \\
\text { and Clark } \\
(2009)\end{array}$ & USA & $\begin{array}{l}\text { Combination of } \\
3 \text { ethnographic } \\
\text { studies }\end{array}$ & $\begin{array}{l}\text { Residents, (staff and } \\
\text { family) in various long- } \\
\text { term care settings }\end{array}$ & $\begin{array}{l}\text { To explore how sexuality and } \\
\text { sexual expression permeate } \\
\text { the lives of assisted living } \\
\text { residents, (the staff working } \\
\text { with them and residents' } \\
\text { family members) }\end{array}$ & $\begin{array}{l}\text { Older residents may still sexually } \\
\text { express themselves in a variety } \\
\text { of ways, going from holding } \\
\text { hands to intercourse. Sexual } \\
\text { interest and behavior is talked } \\
\text { about metaphorically. Residents' } \\
\text { sexual orientation is often } \\
\text { concealed. }\end{array}$ \\
\hline 5. & $\begin{array}{l}\text { Hubbard } \\
\text { et al. } \\
(2003)\end{array}$ & Scotland & $\begin{array}{l}\text { Ethnographic } \\
\text { study }\end{array}$ & $\begin{array}{l}\text { Older residents with and } \\
\text { without dementia } \\
\text { dispersed over } 4 \text { different } \\
\text { care settings of which one } \\
\text { setting was a dementia } \\
\text { unit of a nursing home }\end{array}$ & $\begin{array}{l}\text { To contribute to the } \\
\text { understanding of social } \\
\text { interaction in institutional care } \\
\text { settings by focusing on social } \\
\text { interaction among residents } \\
\text { with and without dementia, to } \\
\text { explore perceptions of quality } \\
\text { of life of frail older people in } \\
\text { institutional care settings }\end{array}$ & $\begin{array}{l}\text { Residents express affection } \\
\text { through joking, teasing, flirting, } \\
\text { passing compliments, proximity } \\
\text { and physical contact. Sexual } \\
\text { relationships are a topic of } \\
\text { conversation among residents. }\end{array}$ \\
\hline 6. & $\begin{array}{l}\text { Nay } \\
(1992)\end{array}$ & Australia & Interview study & $\begin{array}{l}20 \text { nursing home } \\
\text { residents living in } \\
5 \text { different nursing homes } \\
\text { aged } 50 \text { or older }\end{array}$ & $\begin{array}{l}\text { To explore the centrality of } \\
\text { sexuality to identity and its } \\
\text { relationship to the } \\
\text { depersonalized perception of } \\
\text { old women }\end{array}$ & $\begin{array}{l}\text { Although initially stating that } \\
\text { they were too old for sex, some of } \\
\text { the female residents did admit } \\
\text { that they still thought of it and } \\
\text { actually missed it but lacked a } \\
\text { partner. All participants } \\
\text { expressed the need for closeness, } \\
\text { sharing, caring and emotional } \\
\text { involvement. }\end{array}$ \\
\hline 7. & $\begin{array}{l}\text { Stein et al. } \\
(2010)\end{array}$ & USA & $\begin{array}{l}\text { Focus group } \\
\text { study }\end{array}$ & $\begin{array}{l}16 \text { older lesbian and gay } \\
\text { people aged } 60-84 ; \\
4 \text { were living in a long- } \\
\text { term care facility, all } 4 \\
\text { were men }\end{array}$ & $\begin{array}{l}\text { To identify psychosocial } \\
\text { challenges faced by lesbian and } \\
\text { gay older people regarding } \\
\text { long-term care }\end{array}$ & $\begin{array}{l}\text { Older gay residents have a } \\
\text { variety of fears specifically } \\
\text { related to their sexual } \\
\text { orientation or identity: the fear } \\
\text { of being neglected or abused by } \\
\text { other residents or care staff, the } \\
\text { fear of being gossiped about or } \\
\text { becoming isolated, the fear of } \\
\text { having to hide their sexual } \\
\text { identity. }\end{array}$ \\
\hline
\end{tabular}


Table 1b (Continued)

\begin{tabular}{|c|c|c|c|c|c|c|}
\hline & Study & Country & Design & Participants & Aim & Key findings \\
\hline 8. & $\begin{array}{l}\text { Tzeng et al. } \\
(2009)\end{array}$ & Taiwan & $\begin{array}{l}\text { Observational } \\
\text { study }\end{array}$ & $\begin{array}{l}12 \text { institutionalized older } \\
\text { people with dementia } \\
\text { residing in } 3 \text { long-term } \\
\text { care facilities [mean } \\
\text { MMSE score: } 12 \text {, mean } \\
\text { Barthel Index score: } 67 \text { ] }\end{array}$ & $\begin{array}{l}\text { To explore the characteristics } \\
\text { and the contexts related to } \\
\text { sexual behavior among older } \\
\text { long-term care residents with } \\
\text { dementia }\end{array}$ & $\begin{array}{l}\text { Residents' sexual behavior was } \\
\text { categorized into } 3 \text { groups: } \\
\text { 'sexual acts with contact with } \\
\text { others', 'sexual acts with non- } \\
\text { contact with others', and 'verbal } \\
\text { sexual behaviors'. Predisposing } \\
\text { factors for sexual activity were } \\
\text { opportunity, availability of a } \\
\text { 'cooperative target' and lack of } \\
\text { privacy. }\end{array}$ \\
\hline 9. & $\begin{array}{l}\text { Villar et al. } \\
(2013)\end{array}$ & Spain & $\begin{array}{l}\text { Vignette } \\
\text { study }\end{array}$ & $\begin{array}{l}47 \text { residents living in } \\
5 \text { different residential } \\
\text { aged care facilities aged } \\
71-96 ; \text { no diagnosis of } \\
\text { cognitive impairment }\end{array}$ & $\begin{array}{l}\text { To investigate the attitudes of } \\
\text { residential aged care residents } \\
\text { toward non-heterosexual } \\
\text { sexual orientation in older co- } \\
\text { residents }\end{array}$ & $\begin{array}{l}\text { To a majority of the participants, } \\
\text { same-sex sexual behavior } \\
\text { between residents triggered } \\
\text { some kind of negative response } \\
\text { ranging from mere avoidance of } \\
\text { the residents in question to } \\
\text { extreme rejection. Some } \\
\text { participants did display neutral } \\
\text { ( } 17 \% \text { ) or positive (15\%) attitudes } \\
\text { toward same-sex relationships } \\
\text { between co-residents. }\end{array}$ \\
\hline 10. & $\begin{array}{l}\text { Villar et al. } \\
(2014 a)\end{array}$ & Spain & $\begin{array}{l}\text { Interview } \\
\text { study }\end{array}$ & $\begin{array}{l}47 \text { residents living in } \\
5 \text { different residential } \\
\text { aged care facilities aged } \\
71-96 ; \text { no diagnosis of } \\
\text { cognitive impairment ( } 53 \\
\text { staff members) }\end{array}$ & $\begin{array}{l}\text { To explore (staff's and) } \\
\text { residents' experiences of } \\
\text { barriers to sexual expression in } \\
\text { residential aged care facilities }\end{array}$ & $\begin{array}{l}\text { Barriers most frequently } \\
\text { addressed by residents are lack } \\
\text { of privacy, poor health, and the } \\
\text { conservative sexual attitudes of } \\
\text { co-residents. About } 40 \% \text { of the } \\
\text { resident participants did not } \\
\text { identify any barriers to sexual } \\
\text { expression in institutionalized } \\
\text { long-term care. }\end{array}$ \\
\hline 11. & $\begin{array}{l}\text { Villar et al. } \\
(2014 b)\end{array}$ & Spain & $\begin{array}{l}\text { Vignette } \\
\text { study }\end{array}$ & $\begin{array}{l}47 \text { residents living in } \\
5 \text { different residential } \\
\text { aged care facilities aged } \\
71-96 ; \text { no diagnosis of } \\
\text { cognitive impairment ( } 53 \\
\text { staff members) }\end{array}$ & $\begin{array}{l}\text { To investigate and compare the } \\
\text { reactions of staff and } \\
\text { residential care facility } \\
\text { residents toward opposite-sex } \\
\text { sexual activity in private } \\
\text { spaces within the facility }\end{array}$ & $\begin{array}{l}\text { While some considered } \\
\text { opposite-sex sexual expression } \\
\text { within institutionalized long- } \\
\text { term care for older people as } \\
\text { normal others perceived it as } \\
\text { inappropriate due to the high age } \\
\text { of those involved or the lack of } \\
\text { privacy. Residents' reactions to } \\
\text { opposite-sex sexual activity } \\
\text { between co-residents ranged } \\
\text { from negative to neutral to } \\
\text { supportive. }\end{array}$ \\
\hline 12. & $\begin{array}{l}\text { Walker et al. } \\
\text { (1998) }\end{array}$ & USA & $\begin{array}{l}\text { Focus } \\
\text { group }\end{array}$ & $\begin{array}{l}4 \text { older men and } 4 \text { older } \\
\text { women residing in a life } \\
\text { care community [divided } \\
\text { over } 2 \text { focus groups]; ( } 2 \\
\text { family members of } \\
\text { residents in a long-term } \\
\text { care facility) }\end{array}$ & $\begin{array}{l}\text { To develop an comprehensive } \\
\text { sexuality training curriculum } \\
\text { for long-term care staff } \\
\text { addressing the topic of aged } \\
\text { sexuality }\end{array}$ & $\begin{array}{l}\text { Older residents are aware of the } \\
\text { potential need for intimacy and } \\
\text { sexuality among their peers. } \\
\text { They do have reservations about } \\
\text { staff intervening with residents' } \\
\text { private lives. }\end{array}$ \\
\hline 13. & $\begin{array}{l}\text { Ward et } \\
\text { al. (2005) }\end{array}$ & UK & $\begin{array}{l}\text { Observational } \\
\text { study }\end{array}$ & $\begin{array}{l}17 \text { residents with a formal } \\
\text { diagnosis of Alzheimer's } \\
\text { Disease residing in } 5 \text { care } \\
\text { homes }\end{array}$ & $\begin{array}{l}\text { To explore descriptions of } \\
\text { sexuality and sexual } \\
\text { expression of people with } \\
\text { dementia residing in long-term } \\
\text { care facilities }\end{array}$ & $\begin{array}{l}\text { Intimacy and sexuality are } \\
\text { expressed through bodily } \\
\text { communication, witty } \\
\text { conversations and physical } \\
\text { closeness. Most residents } \\
\text { preferred to engage in same-sex } \\
\text { friendships. }\end{array}$ \\
\hline 14. & $\begin{array}{l}\text { Zeiss et } \\
\text { al. (1996) }\end{array}$ & USA & $\begin{array}{l}\text { Observational } \\
\text { study }\end{array}$ & $\begin{array}{l}40 \text { male residents } \\
\text { diagnosed with dementia } \\
\text { aged } 60-98 \text { living in } 3 \\
\text { different long-term care } \\
\text { facilities }\end{array}$ & $\begin{array}{l}\text { To conduct an observational } \\
\text { study of sexual behavior in } \\
\text { residents with dementia }\end{array}$ & $\begin{array}{l}\text { Incidences of sexual behavior of } \\
\text { any kind (i.e. appropriate, } \\
\text { ambiguous, and inappropriate } \\
\text { sexual behaviors) are rather } \\
\text { uncommon among older long- } \\
\text { term care residents diagnosed } \\
\text { with dementia }\end{array}$ \\
\hline
\end{tabular}

PR: participation rate. 
Table 2

Quality assessment of the included literature.

\begin{tabular}{llllll}
\multicolumn{2}{l}{ Clear description of... } & & & \\
\hline $\begin{array}{l}\text { Aim/research } \\
\text { question }\end{array}$ & $\begin{array}{l}\text { Background } \\
\text { literature }\end{array}$ & $\begin{array}{l}\text { Study design } \\
\text { and procedure }\end{array}$ & $\begin{array}{l}\text { Sampling } \\
\text { method, } \\
\text { incl./excl. } \\
\text { Criteria }\end{array}$ & $\begin{array}{l}\text { Data collection } \\
\text { and analysis }\end{array}$ & $\begin{array}{l}\text { Ethical } \\
\text { considerations }\end{array}$ \\
\end{tabular}

\begin{tabular}{|c|c|c|c|c|c|c|c|c|}
\hline \multicolumn{9}{|c|}{ Qualitative studies } \\
\hline 1. & Bauer et al. (2013) & + & + & + & + & + & + & + \\
\hline 2. & Donaldson et al. (2014) & + & + & + & + & + & + & + \\
\hline 3. & Ehrenfeld et al. (1999) & + & $-1+$ & + & + & + & + & + \\
\hline 4. & Frankowski \& Clark (2009) & + & + & $-1+$ & $-1+$ & + & $-1+$ & + \\
\hline 5. & Hubbard et al. (2003) & $-1+$ & + & + & + & $-1+$ & + & $-1+$ \\
\hline 6. & Nay (1992) & + & - & $-1+$ & $-1+$ & $-1+$ & - & $-1+$ \\
\hline 7. & Stein et al. (2010) & + & + & + & + & + & + & + \\
\hline 8. & Tzeng et al. (2009) & + & + & + & + & + & + & + \\
\hline 9. & Villar et al. (2013) & + & + & + & + & + & + & + \\
\hline 10. & Villar et al. (2014a) & + & + & + & + & + & + & + \\
\hline 11. & Villar et al. (2014b) & + & + & + & + & + & + & + \\
\hline 12. & Walker et al. (1998) & + & + & + & - & $-1+$ & + & $-1+$ \\
\hline 13. & Ward et al. (2005) & $-1+$ & + & $-1+$ & $-1+$ & $-1+$ & $-1+$ & $-1+$ \\
\hline 14. & Zeiss et al. (1996) & + & $-1+$ & + & $-1+$ & + & + & + \\
\hline \multicolumn{9}{|c|}{ Quantitative studies } \\
\hline 1. & Aizenberg et al. (2002) & + & $-1+$ & $-1+$ & + & $-1+$ & + & + \\
\hline 2. & $\begin{array}{l}\text { Bretschneider and } \\
\text { McCoy (1988) }\end{array}$ & $-1+$ & $-1+$ & + & + & + & + & + \\
\hline 3. & Bullard-Poe et al. (1994) & + & - & + & + & + & $-1+$ & + \\
\hline 4. & De Bruyn (1980) & $-1+$ & + & $-1+$ & + & $-1+$ & $-1+$ & $-1+$ \\
\hline 5. & Gibson et al. (1999) & + & + & + & + & + & + & + \\
\hline 6. & Hesse et al. (1980) & + & + & $-1+$ & + & + & $-1+$ & + \\
\hline 7. & Mroczek et al. (2013) & + & + & + & + & + & + & + \\
\hline 8. & Mulligan \& Palguta (1991) & + & $-1+$ & $-1+$ & + & + & $-1+$ & + \\
\hline 9. & Spector \& Fremeth (1996) & + & + & + & + & + & + & + \\
\hline 10. & Story (1989) & + & + & + & + & + & + & + \\
\hline 11. & White (1982) & + & + & + & + & + & $-1+$ & + \\
\hline
\end{tabular}

was any doubt or disagreement on the inclusion of a study, the article in question was discussed until consensus was reached. Articles were read repeatedly to obtain an overall understanding of the material. Relevant passages were isolated, summarized on the data extraction form, compared, related and categorized according to theme. This inductive analysis of the study data allowed for the development of descriptive themes which were later on used as a baseline to structure the result section.

\section{Results}

\subsection{Characteristics of the included studies}

The majority of the 25 eligible publications originated from the USA $(n=10)$. The remaining studies were conducted in various countries including the following: Spain $(n=3)$, Australia $(n=2)$, Canada $(n=2)$, Israel $(n=2)$, Germany, The Netherlands, Poland, Scotland, Taiwan, and the UK ( $n=1$ respectively). The publication year range of the included studies spreads over a considerable period from the 1980 s to 2014 . Nearly half of the studies $(n=12)$ were published from 2000 onwards.

A variety of research methodologies were used by the 14 qualitative studies included in this review. Of these studies, 4 used interviews; the others opted for the use of focus groups $(n=2)$, vignettes $(n=2)$ or an ethnographic or observational design $(n=6)$. All quantitative studies included, except for one, used a self-developed measuring instrument or an already established questionnaire such as the Ageing Sexual Knowledge and Attitudes Scale (ASKAS) (used by Spector and Fremeth, 1996 and White, 1982), the Sexual Desire Inventory (used by Spector and Fremeth, 1996), or the Adult Sexuality Knowledge and Attitude Test (ASKAT) (used by Story, 1989 ) to collect data. Bullard-Poe et al. (1994) administered a series of vignettes depicting various scenarios of aged sexuality.

Reported sample sizes ranged from 4 to 250 . It is worth noting that the focus group studies had the smallest sample sizes. Especially with regard to the ethnographic and/or observational studies, concrete information on sample sizes and participant profiles was scarce. In general, however, participants were aged 42-102 and resided in an institutional care setting such as an assisted living facility, a senior citizens' residence, a retirement or residential home, a chronic care hospital, a care home, a home for elderly, or a nursing home. Most studies included both male and female participants. A minority, however, solely focused on older male residents $(n=5$; Bullard-Poe et al., 1994; Mulligan and Palguta, 1991; Stein et al., 2010; Tzeng et al., 2009; Zeiss et al., 1996). One study explicitly sought for older gay participants (Stein et al., 2010). While some of the studies limited their study population to older people with a diagnosis of dementia (Ehrenfeld et al., 1999; Tzeng et al., 2009; Ward et al., 2005; Zeiss et al., 1996); 
others were rather vague about the required cognitive abilities of participants, only sought for cognitively intact residents or included both residents with and without dementia. Most studies including residents with dementia used an observational design and thus reported on the intimate and sexual behavior of these residents rather than offering an insight in the residents' own perspectives on aged sexuality (Ehrenfeld et al., 1999; Hubbard et al., 2003; Tzeng et al., 2009; Ward et al., 2005; Zeiss et al., 1996). A systematic presentation of the characteristics of the included studies can be found in Table 1a (quantitative studies) and Table 1b (qualitative studies).

\subsection{Sexual expression in institutionalized care settings}

Interest in sex is resident dependent (Frankowski and Clark, 2009; Hesse et al., 1980). Aizenberg et al. (2002) found sex to be moderately important to nursing home residents when compared to mood, memory, sleep and appetite. Bullard-Poe et al. (1994), in their turn, reported that sexualphysical intimacy is perceived as less important than emotional intimacy, intellectual intimacy, non-sexual physical intimacy, and social intimacy. This seems to coincide with the findings of Mroczek et al. (2013). Within this study physical closeness, intimate contact and living together were rated as less important than mental closeness, tenderness, conversation, respect and support by both men and women. In Bretschneider and McCoy (1988), 66\% of the male and 38\% of the female participants found their sexual lives to be of at least average importance at the moment of participation. Percentages were significantly higher when asking about past importance of sex and sexuality; $82 \%$ of the men and $67 \%$ of the women said that sex was of average or greater importance in their younger years.

Even when older people are no longer interested in coitus, they might still attach great importance to other expressions of sexuality or intimacy (Bauer et al., 2013). Some resident indicate that they still think about sex and are interested in sex but that opportunities for sexual engagement are lacking within residential aged care facilities (Bauer et al., 2013; Frankowski and Clark, 2009; Nay, 1992; Villar et al., 2014a; White, 1982).

\subsection{An unconducive environment?}

Residents' perceptions of the predominant ethos and attitude toward sexuality within their residence do have an impact on their sexual expression and on whether they feel sexually satisfied or not (Spector and Fremeth, 1996). Institutional care settings indeed tend to impose barriers upon residents' sexual expression. Well-known barriers are, for instance, the overall lack of privacy in residential care settings (Bauer et al., 2013; De Bruyn, 1980; Spector and Fremeth, 1996; Villar et al., 2014a; Ward et al., 2005; White, 1982), the knowledge and attitudes of staff (Bauer et al., 2013; Stein et al., 2010; Villar et al., 2014a), residents (Villar et al., 2014a), and family members (Villar et al., 2014a), the amenities available (Bauer et al., 2013; De Bruyn, 1980; Hubbard et al., 2003; Ward et al., 2005), the lack of communication about sex and sexuality (Bauer et al., 2013; Spector and Fremeth, 1996; Villar et al., 2014a), poor health
(Villar et al., 2014a), and the lack of a partner (Bauer et al., 2013; Nay, 1992; Villar et al., 2014a; White, 1982). As Mulligan and Palguta (1991) point out, ones interest in sex might increase with the availability of a partner. When it comes to seeking out a new potential partner, a variety of characteristics and qualities seem to be taken into consideration (Hesse et al., 1980). Single residents mainly seem to look for a trustworthy, helpful partner that gives them a sense of security. Although a potential partner does not need to look youthful, a neat appearance is definitely considered an advantage by most of the interviewees. For one fifth of the participants a potentially new partner has to be willing to engage in physical intimacy (Hesse et al., 1980).

Not all residents, however, experience their stay at a residential care facility as an impediment to their sexual lives. The barriers identified above might thus not be relevant to all. In fact, $40 \%$ of the residents participating in the study conducted by Villar et al. (2014a) were unable to identify any barriers related to sexual expression. It might be argued that, for these residents, sexuality and sexual expression do not - or no longer - hold a significant place in their lives (Bauer et al., 2013; Frankowski and Clark, 2009; Villar et al., 2014a). In Bretschneider and McCoy (1988) more than $60 \%$ of the participants said that staying in a residential home, as such, did not intervene in their sexual lives, whereas nearly $20 \%$ said it clearly prevented them from being sexually active.

\subsection{Sexual interest, behaviors and satisfaction}

Residents who do wish to express themselves sexually do this through a wide variety of behaviors ranging from emotional, intellectual and social intimacy to intercourse (Frankowski and Clark, 2009). Within institutionalized elderly care, residents' sexuality might be expressed through daydreaming (Bretschneider and McCoy, 1988; De Bruyn, 1980), reminiscing (Bauer et al., 2013; De Bruyn, 1980; Mroczek et al., 2013), reading romantic or erotic books (De Bruyn, 1980; Spector and Fremeth, 1996), dressing up (Bauer et al., 2013; De Bruyn, 1980), making witty flirtatious remarks (Hubbard et al., 2003), giving compliments (Frankowski and Clark, 2009; Hubbard et al., 2003), proximity (Hubbard et al., 2003), hand holding (Frankowski and Clark, 2009; Hubbard et al., 2003), hugging (Spector and Fremeth, 1996; Tzeng et al., 2009), touching (Bretschneider and McCoy, 1988; Frankowski and Clark, 2009; Hubbard et al., 2003; Spector and Fremeth, 1996), stroking or caressing (Bretschneider and McCoy, 1988; Hubbard et al., 2003; Mulligan and Palguta, 1991; Spector and Fremeth, 1996; Tzeng et al., 2009), kissing (Frankowski and Clark, 2009; Hubbard et al., 2003; Mroczek et al., 2013; Mulligan and Palguta, 1991; Spector and Fremeth, 1996; Tzeng et al., 2009), fascination (Mroczek et al., 2013), intercourse (Bretschneider and McCoy, 1988; Mroczek et al., 2013; Mulligan and Palguta, 1991; Spector and Fremeth, 1996), oral sex (Bretschneider and McCoy, 1988), and masturbation (Bretschneider and McCoy, 1988; De Bruyn, 1980; Frankowski and Clark, 2009; Mulligan and Palguta, 1991; Spector and Fremeth, 1996).

Mroczek et al. (2013) found sexual tension to be relieved by, for instance, masturbation and watching erotic 
movies. In Mulligan and Palguta (1991) 90\% of the participants reported not to masturbate. This largely corresponds with the research results of Spector and Fremeth (1996). When interpreting these numbers, it might be interesting to consider the apparent taboo character of masturbation. Bretschneider and McCoy (1988) report a high reluctance among their participants to answer questions specifically dealing with masturbation. Sexual desire levels for both dyadic and solitary sexual activity as well as masturbation frequency rates appear to be significantly higher among men than women (Bretschneider and McCoy, 1988; Spector and Fremeth, 1996). When it comes to engaging in masturbation as a solitary sexual activity having a partner or not seems to be irrelevant (Mulligan and Palguta, 1991).

In the study conducted by Mroczek et al. (2013) 51\% claimed to feel sexual tension, and $24.7 \%$ remained sexually active. Only 39\%, however, said their psychosexual needs were met. Rates for sexual satisfaction were remarkably higher in the study of Mulligan and Palguta (1991). Most of the male nursing home residents participating in their study, indicated to be relatively satisfied sexually. Spector and Fremeth (1996), however, observed sexual satisfaction levels to be significantly lower in men than in women. Sexual satisfaction was found to be tied in with perceived emotional health (Spector and Fremeth, 1996). In De Bruyn (1980), residents indicated to no longer engage in sexual intercourse. In the study conducted by White in 1982, only 9\% of the participants characterized as sexually active. Although vaginal intercourse was preferred by a majority of the participants in Mulligan and Palguta (1991), only 20\% of the respondents who had a partner still engaged in sexual intercourse. Sexual activity rates in the study of Bretschneider and McCoy (1988) were relatively high; nearly two-thirds of the male participants and one-third female participants claimed to still engage in sexual intercourse. All participants in this study were both physically and mentally healthy and thus highly care independent (Bretschneider and McCoy, 1988). In the study conducted by Spector and Fremeth (1996), about $12 \%$ of the respondents had had some kind of dyadic sexual activity including kissing, hugging, caressing and intercourse. Frequency scores were even lower with regard to solitary sexual activity (Spector and Fremeth, 1996). According to White (1982), the sexual history of older residents might be looked upon as a strong predictor of current sexual activity. This, however, might not be the case with regard to the frequency of sexual intercourse. Bretschneider and McCoy (1988) detected significant correlations between past and present importance of sex, between past and present initiation of sexual encounters and between past and present engagement in and enjoyment of touching and caressing without having sexual intercourse, as well as masturbation.

\subsection{Residents with dementia}

Sexual frequency levels appear to be rather low in older residents with dementia as well (Zeiss et al., 1996). Sexually appropriate behaviors were displayed by $20 \%$ of the residents studied. Sexually inappropriate and ambiguous behaviors were found in $18 \%$ and $28 \%$ of the residents, respectively. According to Ehrenfeld et al. (1999), most sexually-based interactions between residents with dementia are initiated by male residents and directed toward a person of the opposite sex. Sexual expression in older residents with dementia, however, might also entail sexual behavior toward same-sex residents, staff and visitors, solitary sexual activity and verbal sexual behavior (Ehrenfeld et al., 1999; Tzeng et al., 2009). Ehrenfeld et al. (1999) identified three categories of sexual behavior expressed by residents with dementia. These categories are love and caring, romance and eroticism. The more sexually explicit the behavior seems to be, the greater the chance for a negative reception from staff and fellow residents (Ehrenfeld et al., 1999). Tzeng et al. (2009, p. 996) identified three predisposing factors for sexual behavior in older residents with dementia, that is (1) the opportunity presenting itself through an accidental meeting, mutual excitement during a group activity or physical contact during daily care, (2) the availability of what the authors call a 'cooperative target', and (3) the lack of privacy even when it comes to residents' private spaces.

\subsection{Attitudes toward sexual expression in institutionalized care settings}

Overall residents' attitudes toward aged sexuality in general - that is as a rather abstract idea - are more positive than their attitudes toward specific sexual behaviors in later life (Story, 1989). However, some residents are convinced that sexually active older residents cut a bad figure (Hesse et al., 1980; Villar et al., 2014b). Occasionally these residents might overtly criticize coresidents' sexual behavior as shameful or embarrassing (Tzeng et al., 2009). Mroczek et al. (2013) investigated the potential influence of certain stereotypes regarding aged sexuality on nursing home residents. Most stereotypes seemed to have been picked up by the participants. A majority of participants, for instance, agreed with the statement that aged sexuality is a taboo and that sex is for young people only. Likewise Nay (1992) argues that older women tend to share social stereotypes and prejudice. In Walker et al. (1998), however, residents did acknowledge that the need for intimacy and sexuality might persist among their peers.

\subsection{Appropriate versus inappropriate sexual behavior}

Important factors in determining the appropriateness of sexual behavior of co-residents are the level of privacy (Gibson et al., 1999; Villar et al., 2014b), the presence of consent (Gibson et al., 1999), the permanence of the partner relationship in case of dyadic sexual activity (Gibson et al., 1999), the marital status of those involved (Story, 1989), the kind of behavior (e.g. same-sex versus opposite-sex sexual behavior) (Donaldson et al., 2014; Villar et al., 2013; Ward et al., 2005) and the potentially disruptive or offensive character of the displayed behavior (Gibson et al., 1999).

Residents seem to attach greater importance to the perceived appropriateness of sexual behaviors than to how 
witnessing these behaviors might affect them emotionally (Villar et al., 2014b). According to Villar et al. (2014b), this might explain why residents seem to be more judgmental with regard to sexual activity in residential care facilities than staff. Residents were markedly more prone than staff to qualify male-female sexual intercourse as inappropriate. Most residents indicated that witnessing two coresidents having sex would excite negative emotions such as unpleasantness and shame or would at the very least take them by surprise. When asked how they would react, most residents said that they would try to ignore the witnessed situation. A minority stated that they would curb co-residents' sexual behavior either indirectly by the use of humor as a form of social control, or in a more direct way by reprimanding the residents involved. Everything taken into consideration, negative responses (i.e. teasing and reprimanding) and neutral reactions (i.e. ignoring, apologizing for the interruption and informing staff) clearly outnumbered positive reactions (Villar et al., 2014b). Likewise, Gibson et al. (1999) found residents to be more prone than staff to ignore inappropriate sexual behavior or to endorse pharmacological treatment of hypersexual or sexually disinhibited behavior.

Attitudes and reactions furthermore seem to be influenced by the religious convictions of the respondents (Donaldson et al., 2014; Story, 1989), their selfrated level of religiosity (Spector and Fremeth, 1996), their cognitive status that is their lucidity and their ability to respond (Ehrenfeld et al., 1999; Tzeng et al., 2009). The impact of religion seems to be highly individual. While some deny the impact of religious beliefs on their attitude toward, for example, homosexuality, others confirm that their religious conviction either negatively or positively influences their attitudes toward same-sex sexuality (Donaldson et al., 2014). Story (1989) found older protestants to hold more positive attitudes toward older people's sexuality than their catholic counterparts and peers with other religious convictions. Spector and Fremeth (1996) furthermore state that the more religious residents are the more likely they are to hold conservative sexual attitudes. Ehrenfeld et al. (1999) saw how residents with dementia might be enabled to place and understand the sexual behavior of co-residents or to control their own reactions to it; simply because they lack the cognitive resources necessary to do so. Likewise, Tzeng et al. (2009) state that people with severe dementia might lack the ability to respond to coresidents' sexual behavior.

\subsection{Heteronormativity and homophobia}

Despite the general increase in acceptance of sexual minorities, attitudes toward diverse sexualities (e.g. lesbian, gay, bisexual and transgender people) remain a tricky issue. Attitudes range from plain disgust to acceptance and support (Donaldson et al., 2014; Frankowski and Clark, 2009; Villar et al., 2013). Residents often do not know whether or not there are any older lesbian, gay, bisexual and transgender (LGBT) people staying at their facility (Donaldson et al., 2014). Sexual orientation is not something they like to address directly with co-residents. Some residents simply prefer not knowing others' sexual orientation (Donaldson et al., 2014).

Frankowski and Clark (2009) found sexual orientation to be a rarely expressed aspect of residents' personal identity. Older LGBT residents might indeed fear the reactions of co-residents and staff (Stein et al., 2010). This fear might be so profound that it sparks of the fear of being neglected, ostracized or abused by other residents or heath care staff because of their sexual orientation (Stein et al., 2010). Because of these fears, non-heterosexual residents might feel the need to hide their sexual orientation and thus go back into the closet.

In the study conducted by Donaldson et al. (2014) some heterosexual residents did indicate that they would be reluctant about socializing with residents they know were gay or lesbian. The results of Villar et al. (2013) support the existence of homophobia in nursing home residents. Almost $30 \%$ of their participants stated that they would avoid any kind of contact with non-heterosexual peers. Others labeled diverse sexualities as abnormal or considered it to be some kind of disease (21.3\% of participants). Feelings of discomfort, disgust and extreme rejection were reported by $21.3 \%, 19.1 \%$, and $6.4 \%$ of the participants, respectively. Some indicated not to be bothered by the presence of LGBT people as long as they did not have to be on intimate terms or share a room (Donaldson et al., 2014). Likewise, nearly half of the participants in the study of Villar et al. (2013) were opposed to sharing a room with a lesbian, gay or bisexual peer. Almost 30\% was reluctant to do so. A majority of the residents, however, would not mind to share public places with non-heterosexual peers (63.9\%). In Stein et al. (2010), the fear of having to share a room with someone who clearly dislikes gay people was reported to be a major challenge by gay residents.

Regardless of their own attitudes toward LGBT people, most residents supposed the attitudes of their heterosexual peers to be negative with regard to diverse sexualities. To some residents this supposed 'negativity' came across as a lack of compassion (Donaldson et al., 2014). Many residents did indeed share positive feelings with regard to LGBT people (Donaldson et al., 2014). According to Villar et al. (2013), however, only a minority of their respondents (15\%) would accept, respect and maybe even support samegender relationships in their facility. In Ward et al. (2005) participating residents with dementia clearly preferred same-sex friendships above all other forms of intimate and sexual behavior, perhaps because of its perceived innocence.

\subsection{Let's talk about sex}

Although sexuality and sexual expression are often considered to be a private matter, some residents might feel the need to discuss their sexual needs with staff (Bauer et al., 2013). The results of Aizenberg et al. (2002) definitely back this up. A majority of their participants held the opinion that health professionals should be prepared to openly discuss sexuality with older residents and expressed the willingness to receive consultation and treatment if needed. Currently, however, only a small minority of residents actually mentions their psychosexual needs to caregivers (Mroczek et al., 2013). 


\section{Discussion}

Whereas most of the literature on aged sexuality in institutionalized elderly care primarily focuses on staff responses to residents' sexual expression (Elias and Ryan, 2011; Mahieu et al., 2011), this review sought to approach the issue from a different angle. Its overall objective was to explore the limited literature available on the thoughts, experiences and involvement of older residents regarding aged sexuality in institutionalized care. Incorporating residents' perspectives when discussing sexual expression in long-term care facilities is a prerequisite for individualized or person-centered nursing care within this domain of life (Mahieu et al., 2014). Even though this might come across as obvious, upholding it - both in research and in practice - often appears to be quite challenging. A topic as intimate and sensitive as aged sexuality is often considered difficult to investigate in an elderly population (Tarzia et al., 2013) or to bring up with older people (Gott, 2005; Gott et al., 2004; Saunamaki and Engstrom, 2014). This becomes even harder when people with dementia are involved.

\subsection{Substantial findings}

Our review demonstrates that older people living in long-term care facilities do indeed still think about sex, even though they are often perceived not to. By doing so it clearly contradicts the myth of asexual old age; a deeply entrenched myth within our western society that also affects health care professionals. In her book 'Sexuality, sexual health and ageing', Gott (2005) distinguishes two trends in contemporary thinking about sexuality and ageing. A first trend points to this myth perpetuating the incompatibility of sexuality and old age. Within this line of thinking, sexuality is attributed to the young, beautiful and healthy which ultimately results in the stigmatization of older people as being either totally inactive and thus normal; or highly inhibited displaying aberrant behavior (Hodson and Skeen, 1994). In recent years, however, a second trend has emerged in which sexual health and activity in old age are actively promoted. Gott (2005) refers to this second stereotypical way of thinking as the myth of the sexy oldies. This myth proclaims sexuality (preferably expressed through sexual intercourse) to be a key aspect of healthy ageing, nearly turning sexual activity into a need or necessity. Based upon this review, we can safely state that the truth about aged sexuality seems to be somewhere in between these two extremes. Overall, sex and sexuality appear to be of relative importance among older residents. When compared to basic needs such as sleep and appetite, sex is scored as moderately important (Aizenberg et al., 2002). Hence, the importance of sex and sexuality to older residents should be neither under- nor overestimated.

Regardless of which stereotype one is inclined to endorse, one must be careful not to impose one's own attitudes of what constitutes appropriate sexual activity (Gott, 2005; Mahieu et al., 2011). The susceptibility of older people to stereotypical thinking about the appropriateness of sexual activity in later life further reinforces this caution (Mroczek et al., 2013). Especially, geriatric nursing staff has to be careful not to be too obtrusive when it comes to residents' sexual expression. Because of their intensive involvement in hands-on-care, and their continuous and often close interaction with older residents, nursing staff indirectly determines whether and which sexual acts are tolerated (Di Napoli et al., 2013; Lyder, 1994). Awareness of their own attitudes toward aged sexuality in institutionalized care settings, is as far as this is concerned, of crucial importance. Both stereotypes leave little room for older people to take up their own position toward sexuality in later life and as such do not reflect the heterogeneity nor complexity identified by the included literature. Bluntly promoting or preventing sexual engagement in older residents without any form of differentiation, shows a lack of attentiveness, understanding and respect on the part of the care provider.

Sexual interest and expression are indeed highly individual. Rather than assuming communality when dealing with aged sexuality, careful attention should be paid to the differences between and among older residents. While some older people wish to continue their sexual life after admission to a long-term care facility, others might choose a life of abstinence. This individuality is also reflected in residents' attitudes toward diverse sexualities and their responses toward the sexual behavior of coresidents. Given the importance of individualized and person-centered care to current healthcare practices, it seems only logical to (also) recognize and respect the highly individual character of aged sexuality. The only way to do this is by taking into account older residents' "needs, experiences, preferences, desires, behaviors, perceptions, feelings and understanding" with regard to sexuality and sexual expression (Suhonen et al., 2014, p. 1358). Research addressing residents' thoughts on, experiences of and engagement in sexual behavior and aged sexuality, nevertheless, proved to be scarce. Only 25 studies spread over a period of 25 years could be included in this review. Within elderly care, the life history of patients is often considered to be of crucial importance in assuring individualized care (Suhonen et al., 2011). When it comes to intimacy and sexuality, the sexual history of older residents appears to be a strong predictor of current sexual activity (White, 1982). When it comes to residents with dementia, however, current behavior might no longer reflect historical life time values and beliefs. A strong focus on the predicting value of residents' sexual history questions the moral permissibility of current, aberrant behaviors and might lead to the pathologization of normal sexual behavior in older people whose sexual expression might have become ambiguous because of dementia (Mahieu et al., 2014; Mahieu and Gastmans, 2012). By rising this issue we do not wish to deny the importance of residents' sexual history in understanding current sexual wishes and behaviors at all. We do, however, wish to recommend caution within this regard. After all, personcentered care puts the patient first, that is the individual "we face [and have to face] here and now" (Nys, 2013, p. 192).

Sexual expression in later-life, furthermore, describes a wide spectrum of behaviors ranging from emotional intimacy and proximity to sexual intercourse. A broad 
definition of sexuality is therefore warranted when discussing aged sexuality in institutionalized elderly care settings (Roelofs et al., 2014). Confining sexuality to explicit sexual activity or breaking it down into constituent behaviors definitely facilitates its description, but does no justice to the complexity of human sexuality (Gott, 2005). Although sexually charged physical intimacy remains important to some (Mulligan and Palguta, 1991), priority seems to be given to other forms of intimacy such as emotional and intellectual closeness and non-sexual physical intimacy (Bauer et al., 2013; Bretschneider and McCoy, 1988; Bullard-Poe et al., 1994; Mroczek et al., 2013).

Bystanders' reactions to residents' sexual expression often differ depending on the behavior displayed by the residents in question and its sexual explicitness. Nursing staff, for instance, might find it harder to deal with overtly erotic and sexual behavior than with rather innocent expressions of love and caring (Ehrenfeld et al., 1999; Mahieu et al., 2011). When it comes to the reactions of older co-residents, the literature indicates that the perceived appropriateness of the displayed behavior is more important than the emotional discomfort that might arise when witnessing the behavior (Villar et al., 2014b). Heteronormativity in residential aged care facilities proves to be a concern of older LGBT residents (Stein et al., 2010). Their fear not to be recognized appears to be not entirely unjustified since most of the included studies addressing older residents' attitudes toward diverse sexualities indeed allude to the existence of homophobia in residential aged care facilities. Research has shown that nursing staff as well are more prone to hold negative attitudes toward same-gender sexual contact than toward heterosexual intimacy (Di Napoli et al., 2013; Hayward et al., 2013; Hinrichs and Vacha-Haase, 2010).

\subsection{Strengths and limitations}

The current review adds to the existing literature by bringing the residents' perspective into prominence. When interpreting the results of this review, however, it is important to consider some methodological issues. This review synthesizes more than 20 years of research (19802014) conducted in a wide variety of countries (i.e. Australia, Canada, Germany, Israel, the Netherlands, Poland, Scotland, Spain, Taiwan, the UK, and the USA), and thus cultures. Its international character affords the possibility of supplying readers a broad, yet nuanced, account of residents' thoughts on, experiences of and involvement in aged sexuality. Even though we deliberately did not limit our search to publications written in English, most of the included literature did originate from English-speaking countries. Chances are that our choice of databases induced a certain bias in the identification of relevant papers as most of the consulted databases seem to focus mainly on Anglo-Saxon literature.

The inclusion of both qualitative and quantitative studies definitely leads to richer information on the topic at hand. The complexity inherent in combining different methodologies, nevertheless, poses some methodological challenges which - according to Whittemore and Knafl
(2005) - can be addressed by paying special attention to the determination of the research purpose, the search strategy, and the process of data collection and synthesis. By clearly defining the specific aim of our review, the search strategy and both the inclusion and exclusion criteria, this review definitely gained in clearness, accuracy and methodological rigor. Differences across the included studies (e.g. differences in study design, and the level of care dependency of the participating residents) have been carefully documented throughout the reviewing process. A detailed account of these differences can be found in the included tables.

\section{Conclusion}

Relatively little work has been published on older residents' perspectives regarding aged sexuality in institutionalized elderly care. If, however, we wish to devote ourselves to individualized or person-centered nursing care, more attention will have to be paid to understanding the needs, expectations, attitudes, experiences and behaviors of residents with regard to (aged) sexuality. This holds several important implication for both nursing practice and research. They both, in their own way, need to shift their focus of attention to the residents themselves and how they experience sexual expression in institutionalized elderly care.

\section{Conflict of interest}

None declared.

\section{Funding}

None declared.

\section{References}

Aizenberg, D., Weizman, A., Barak, Y., 2002. Attitudes toward sexuality among nursing home residents. Sexual. Disabil. 20, 185-189.

Bauer, M., McAuliffe, L., Nay, R., 2007. Sexuality, health care and the older person: an overview of the literature. Int. J. Older People Nurs. 2, 63-68.

Bauer, M., Fetherstonhaugh, D., Tarzia, L., Nay, R., Wellman, D., Beattie, E. 2013. I always look under the bed for a man. Needs and barriers to the expression of sexuality in residential aged care. Psychol. Sexual. 4 (3), 296-309.

Bretschneider, J.G., McCoy, N.L., 1988. Sexual interest and behavior in healthy 80- to 102-year-olds. Arch. Sex. Behav. 17, 109-129.

Bullard-Poe, L., Powell, C., Mulligan, T., 1994. The importance of intimacy to men living in a nursing home. Arch. Sex. Behav. 23, 231-236.

Bouman, W.P., Arcelus, J., Benbow, S.M., 2006. Nottingham study of sexuality and ageing (NoSSA I). Attitudes regarding sexuality and older people: a review of the literature. Sex. Relation. Ther. 21, 149161.

De Bruyn, J.W.G., 1980. Een proefonderzoek naar de seksualiteitsbeleving van hoogbejaarden in een verzorgingstehuis.(A pilot study on the sexual experience of elderly nursing home residents). Gerontologie 11 (3), 197-203.

Di Napoli, E.A., Breland, G.L., Allen, R.S., 2013. Staff knowledge and perceptions of sexuality and dementia in older adults in nursing homes. J. Aging Health 25 (7), 1087-1105.

Delamater, J., 2012. Sexual expression in later life: a review and synthesis. J. Sex Res. 49 (2-3), 125-141.

Donaldson, W.V., Asta, E.L., Vacha-haase, T., 2014. Attitudes of heterosexual assisted living residents toward gay and lesbian peers Clin. Gerontol. 37 (2), 167-189 
Ehrenfeld, M., Bronner, G., Tabak, N., Alpert, R., Bergman, R., 1999. Sexuality among institutionalized elderly patients with dementia. Nurs. Ethics 6 (2), 144-149.

Elias, J., Ryan, A., 2011. A review and commentary on the factors that influence expressions of sexuality by older people in care homes. J. Clin. Nurs. 20, 1668-1678.

Frankowski, A.C., Clark, L.J., 2009. Sexuality and intimacy in assisted living: residents' perspectives and experiences. Sexual. Res. Social Policy 6, 25-37.

Gibson, M.C., Bol, N., Woodbury, G., Beaton, C., 1999. Comparison of caregivers', residents', and community-dwelling spouses' opinions about expressing sexuality in an institutional setting. J. Gerontol. Nurs. 25, 30-39.

Gott, M., 2005. Sexuality, Sexual Health and Ageing. Open University Press, Berkshire.

Gott, M., Galena, R., Hinchliff, S., Elford, H., 2004. Opening a can of worms: GP and practice nurse barriers to talking about sexual health in primary care. Fam. Pract. 21 (5), 528-536.

Greenhalgh, T., Peacock, R., 2005. Effectiveness and efficiency of search methods in systematic reviews of complex evidence: audit of primary sources. BMJ 331, 1064-1065.

Hajjar, R.R., Kamel, H.K., 2003. Sexuality in the nursing home. Part 1. Attitudes and barriers to sexual expression. J. Am. Dir. Assoc. 4, 152-156.

Hayward, L.E., Robertson, N., Knight, C., 2013. Inappropriate sexual behaviour and dementia: an exploration of staff experiences. Dementia $12,463-480$

Hesse, G., Kuhlmey, J., Lautsch, E., 1980. Alter und Sexualität in der Sicht von Feierabend- und Pflegeheimbewohnern.(Age and sexuality from the point of view of inhabitants of homes for the aged geriatric nursing homes). Zeit. Alternsforsch. 35, 303-322.

Hinrichs, K.L., Vacha-Haase, T., 2010. Staff perceptions of same-gender sexual contacts in long-term care facilities. J. Homosexual. 57, 776-789.

Hodson, D., Skeen, P., 1994. Sexuality and aging: the hammerlock of myths. J. Appl. Gerontol. 13, 219-235.

Hubbard, G., Tester, S., Downs, M.G., 2003. Meaningful social interactions between older people in institutional care settings. Ageing Soc. 23, 99-114.

Liberati, A., Altman, D.G., Tetzlaff, J., Mulrow, C., Gøtzsche, P.C., et al., 2009. The PRISMA statement for reporting systematic reviews and meta-analyses of studies that evaluate health care interventions: explanation and elaboration. BMJ 339, b2700, http://dx.doi.org/ 10.1136/bmj.b2700.

Lyder, C.H., 1994. The role of the nurse practitioner in promoting sexuality in the institutionalized elderly. J. Am. Assoc. Nurse Acad. Nurse Pract. $6,61-63$.

Mahieu, L., Van Elssen, K., Gastmans, C., 2011. Nurses' perceptions of sexuality in institutionalized elderly: a literature review. Int. J. Nurs. Stud. 48, 1140-1154.

Mahieu, L., Gastmans, C., 2012. Sexuality in institutionalized elderly persons: a systematic review of argument-based ethics literature. Int. Psychogeriatr. 24, 346-357.

Mahieu, L., Anckaert, L., Gastmans, C., 2014. Intimacy and sexuality in institutionalized dementia care: clinical-ethical considerations. Health Care Anal., http://dx.doi.org/10.1007/s10728-014-0287-2, [epub ahead of print].

Makimoto, K., Kang, H.S., Yamakawa, M., Konno, R., 2014. An integrated literature review on sexuality of elderly nursing home residents with dementia. Int. J. Nurs. Pract., http://dx.doi.org/10.1111/ijn.12317, [epub ahead of print].

Mroczek, B., Kurpas, D., Gronowska, M., Kotwas, A., Karakiewicz, B., 2013. Psychosexual needs and sexual behaviors of nursing care home residents. Arch. Gerontol. Geriatr. 57, 32-38.

Mulligan, T., Palguta, R.F., 1991. Sexual interest, activity, and satisfaction among male nursing home residents. Arch. Sex. Behav. 20, 199-204.

Nay, R., 1992. Sexuality and aged women in nursing homes. Geriatric Nurs. 13 (6), 312-314.

Nys, T., 2013. The wreckage of our flesh: dementia autonomy and personhood. In: Denier, Y., Gastmans, C., Vandevelde, A. (Eds.), Justice, Luck \& Responsibility in Health Care: Philosophical Background and
Ethical Implications for End-of-Life Care. Springer, Dordrecht, pp. 189-203.

Parker, S., 2006. What barriers to sexual expression are experienced by older people in 24-hour care facilities? Rev. Clin. Gerontol. 16, 275-279.

Roelofs, T.S.M., Luijkx, K.G., Embregts, P.J.C.M., 2014. Intimacy and sexuality of nursing residents with dementia: a systematic review. Int. Psychogeriatr., http://dx.doi.org/10.1017/S1041610214002373, [epub ahead of print].

Rosen, T., Lachs, M.S., Pillemer, K., 2010. Sexual aggression between residents in nursing homes: literature synthesis of an underrecognized problem. J. Am. Geriatr. Soc. 58, 1070-1079.

Spector, I.P., Fremeth, S.M., 1996. Sexual behaviors and attitudes of geriatric residents in long-term care facilities. J. Sex Marital Ther. 22, 235-246.

Saunamaki, N., Engstrom, M., 2014. Registered nurses' reflections on discussing sexuality with patients: responsibilities, doubts and fears. J. Clin. Nurs. 23, 531-540.

Stein, G.L., Beckerman, N.L., Sherman, P.A., 2010. Lesbian and gay elders and long-term care: identifying the unique psychosocial perspectives and challenges. J. Gerontol. Social Work 53, 421-435.

Story, M.D., 1989. Knowledge and attitudes about the sexuality of older adults among retirement home residents. Educ. Gerontol. 15, 515-526.

Suhonen, R., Stolt, M., Puro, M., Leino-Kilpi, H., 2011. Individuality in older people's care: challenges for the development of nursing and nursing management. J. Nurs. Manage. 19, 883-896.

Suhonen, R., Stolt, M., Gustafsson, M.-L., Katajisto, J., Charalambous, A., 2014. The associations among the ethical climate, the professional practice environment and individualized care in care settings for older people. J. Adv. Nurs. 70 (6), 1356-1368.

Tarzia, L., Bauer, M., Fetherstonhaugh, D., Nay, R., 2013. Interviewing older people in residential aged care about sexuality: difficulties and challenges. Sexual. Disabil. 31, 361-371.

Tucker, I., 2010. Management of inappropriate sexual behaviors in dementia: a literature review. Int. Psychogeriatr. 22, 683-692.

Tzeng, Y.L., Lin, L.-C., Lotus Shyr, Y.-I., Wen, J.-K., 2009. Sexual behaviour of institutionalised residents with dementia: a qualitative study. J. Clin. Nurs. 18, 991-1001.

Villar, F., Serrat, R., Fabà, J., Celdrán, M., 2013. As long as they keep away from me: attitudes toward non-heterosexual sexual orientation among residents living in Spanish residential aged care facilities. Gerontologist, http://dx.doi.org/10.1093/geront/gnt150, [epub ahead of print].

Villar, F., Celdrán, M., Fabà, J., Serrat, R., 2014a. Barriers to sexual expression in residential aged care facilities (RACFs): comparison of staff and residents' views. J. Adv. Nurs. 70 (11), 2518-2527.

Villar, F., Fabà, J., Serrat, R., Celdrán, M., 2014b. What happens in their bedrooms stays in their bedrooms: staff and residents' reactions toward male-female sexual intercourse in residential aged care facilities. J. Sex Res., http://dx.doi.org/10.1080/00224499.2014. 959882, [epub ahead of print].

Walker, B.L., Osgood, N.J., Ephross, P.H., Richardson, J.P., Farrar, B., Cole, C., 1998. Developing a training curriculum on elderly sexuality for long term care facility staff. Gerontol. Geriatr. Educ. 19, 3-22.

Ward, R., Vass, A.A., Aggarwal, N., Garfield, C., Cybyk, B., 2005. A kiss is still a kiss? The construction of sexuality in dementia care. Dementia 4, 49-72.

White, C.B., 1982. Sexual interest, attitudes, knowledge, and sexual history in relation to sexual behavior in the institutionalized aged. Arch. Sex. Behav. 11 (1), 11-21.

Whittemore, R., Knafl, K., 2005. The integrative review: updated methodology. J. Adv. Nurs. 52 (5), 546-553.

WHO, 2006. Defining Sexual Health: Report of a Technical Consultation on Sexual Health, 28-31 January 2002, Geneva. World Health Organization, Geneva. Available at: http://www.who.int/ reproductivehealth/publications/sexual_health/defining_sexual_ health.pdf (accessed 10.12.14).

Zeiss, A.M., Davies, H.D., Tinklenberg, J.R., 1996. An observational study of sexual behavior in demented male patients. J. Gerontol. 51A (6), M325-M329. 